\title{
Preliminary Study on Renal Ultrasound Biometry in Apparently Healthy 18 to 30-Year-Old Subjects with Normal Renal Function in Ouagadougou
}

\author{
Gérard Coulibaly ${ }^{*}$, Boubakar Ouattara², Gloria D. M. H. Capo-Chichi'², Tiéba Millogo ${ }^{3}$, \\ Aïda H. Y. Lengani' ${ }^{1}$, Aoua Semde ${ }^{4}$, Gaoussou Sanou${ }^{1}$, Amidou Sawadogo ${ }^{4}$, \\ Balkissa Ouattara ${ }^{5}$, Ousséini Diallo²
}

\footnotetext{
${ }^{1}$ Nephrology and Haemodialysis Department of Yalgado Ouedraogo University Hospital Center of Ouagadougou, Ouagadougou, Burkina Faso

${ }^{2}$ Imaging Department of Yalgado Ouedraogo University Hospital Center of Ouagadougou, Ouagadougou, Burkina Faso ${ }^{3}$ Health Sciences Research Institute, Ouagadougou, Burkina Faso

${ }^{4}$ Nephrology-Dialysis Department of Sourô Sanou University Hospital Center of Bobo-Dioulasso, Bobo-Dioulasso, Burkina Faso ${ }^{5}$ Omaha, Nebraska, USA

Email: *coulibalygerard@hotmail.fr, tibouattara2000@yahoo.fr, gloriahoulette91@gmail.com, millogorod@gmail.com, aidalengani@yahoo.fr, semdaoua@yahoo.fr, sgaoussou84@yahoo.fr, sawadou10@yahoo.fr, balkissouatt@gmail.com, odiallo75@yahoo.fr
}

How to cite this paper: Coulibaly, G., Ouattara, B., Capo-Chichi, G.D.M.H., Millogo, T., Lengani, A.H.Y., Semde, A., Sanou, G., Sawadogo, A., Ouattara, B. and Diallo, O. (2020) Preliminary Study on Renal Ultrasound Biometry in Apparently Healthy 18 to 30-Year-Old Subjects with Normal Renal Function in Ouagadougou. Open Journal of Nephrology, 10, 388-402. https://doi.org/10.4236/ojneph.2020.104039

Received: November 12, 2020 Accepted: December 19, 2020 Published: December 22, 2020

Copyright $\odot 2020$ by author(s) and Scientific Research Publishing Inc. This work is licensed under the Creative Commons Attribution International License (CC BY 4.0).

http://creativecommons.org/licenses/by/4.0/

\section{(c) (i) Open Access}

\begin{abstract}
Introduction: In our practice, renal measurements in patients with normal renal function usually appear to be lower compared to standards reported in reference literature. The standards are probably different in our context. Given the importance of renal biometrics in nephrological practice, we felt it necessary to carry out this preliminary study in order to identify an order of reference measurements appropriate to our context. Methods: This was a cross-sectional study that took place from 18 August to 04 November 2018 at the Yalgado Ouedrarogo University Hospital Center. The first 100 subjects aged between 18 and 30 years who met the following inclusion criteria were selected: to be black african Burkinabe and to have normal renal function. The height, width and thickness of each kidney were measured using ultrasound scanners. For statistical tests, a value of $\mathrm{p}<0.05$ was considered statistically significant. Results: The average age was $23.9 \pm 6.1$ years and the sex ratio was 2.2. Mean heights, widths and renal thicknesses were $94.5 \pm$ $14.5,38.7 \pm 10.7$ and $36.3 \pm 10.3 \mathrm{~mm}$, and $96.7 \pm 16.7,42.7 \pm 16.7$ and $36.8 \pm$ $10.8 \mathrm{~mm}$ respectively for right and left kidneys. The distribution of the different renal dimensions in our sample followed a normal distribution. In the particular case of the right kidney, the probability that its height was
\end{abstract}


between 79.2 and $109.7 \mathrm{~mm}$ was 0.95 and the probability that it was less than $79.2 \mathrm{~mm}$ or greater than $109.7 \mathrm{~mm}$ was 0.05 . Renal height was significantly higher in subjects with height greater than $1.70 \mathrm{~m}(\mathrm{p} \leq 0.02)$. The left kidneys were on average significantly larger than the right kidneys $(p=0.0001)$. Conclusions: Our study is not extrapolable to the general population of Burkina Faso. It suggests, however, that the kidneys of the apparently healthy Burkinabe subject are smaller than what is reported in anatomy reference books. Our work, which is preliminary, should be deepened through a national survey. In the meantime, we should consider, in the nephrological assessment of the Burkinabe patient, the results of the renal biometrics we report.

\section{Keywords}

Black African, Burkina Faso, Renal Biometrics, Ultrasounds Scanner

\section{Introduction}

Ultrasonography is an imaging technique that relies on the use of ultrasound. Because of its safety and accessibility, it is the first-line for the exploration of renal parenchyma and vessels. It allows, in association with the laboratory tests, the early diagnosis of renal disease expressed by a morphological and/or structural abnormality of the kidneys.

The knowledge of renal biometry provides essential morphometric parameters. It reports changes in kidney size during renal disease helping doctors to make a diagnostic and therapeutic decision. This assumes a prior knowledge of normal kidney size. While studies have been done in western countries to evaluate normal kidney biometrics, estimating the height at $120 \mathrm{~mm}$, the width at $60 \mathrm{~mm}$, and the thickness at $30 \mathrm{~mm}$; only a few studies in black Africa were devoted to this question [1]. As a Consequence, African healthcare centers are using western countries reference ranges, which are not always adapted to Black African. Indeed, the kidney size varies from one population to another, also depend on age, weight, height, sex, and origin [2]. A study done among adults in Benin, found the kidney size to be well below western countries numbers [3]. However, can these results be generalized to other black African populations?

In our practice, renal measurements in patients with normal kidney function usually appear to be lower compared to normal values reported in literature. The normal values are probably different in our context. Given the importance of renal biometrics in nephrology, we deemed necessary to carry out this preliminary study to identify normal reference values appropriated to our context.

\section{Methods}

We conducted a descriptive and analytical cross-sectional study between August 
18 and November 04, 2018 in the imaging department of the Yalgado Ouedraogo University Hospital Center (CHU-YO).

The study population included students and individual accompanying patients aged 18 to 30 years. We chose a convenience sample. The selection of subjects was done using brochures in CHU-YO, and The Universities Ouaga I Pr Joseph KI-ZERBO and Saint Thomas Aquin. Empirically, the first 100 subjects meeting the inclusion criteria were selected.

The inclusion criteria were:

- be black and have at least a parent and grandparent Burkinabe.

- age between 18 and 30 years.

- be apparently in good health:

- no past medical history of acute or chronic kidney disease, high blood pressure, clinically detectable heart or liver failure, diabetes mellitus, edema, hematuria, pyuria;

- normal urine dipstick test for albumin, red blood cells, leukocytes, glucose, urinary density, nitrite;

- a normal glomerular filtration rate (GFR), estimated by the the modification of diet in renal disease (MDRD);

- even and symmetrical kidneys, with normal echogenicity and without structural abnormalities.

We did not include pregnant women in the study.

The data were collected using a standardized questionnaire, completed by the same interviewer at each interview with the subjects. The studied variables were renal biometrics, and socio-demographic, clinical and biological data (plasma urea, creatinine). A leaflet explaining the objectives of the study was given to the participants. For those who could not read, it was described to them in the language of their choice.

The data were collected anonymously. The obtained results were only shared with the subjects who wanted it. The brand of the ultrasound machine used was Toshiba $^{\mathrm{Tm}}$ or General Electric ${ }^{\mathrm{Tm}}$. Each of the two reference radiologists weres performed at least two measurements per patient. The average of these measurements (expressed in millimeters) for each subject was used.

The length was measured on a longitudinal section through the long axis between the two poles. The width measurement was made on a cross-section, corresponding to the distance between the hilum and the lateral edge. The thickness was measured on a transverse section through the hilum between the anterior and posterior surfaces and perpendicular to the width.

In order to be operational, renal ultrasound biometrics were defined by the method of ultrasound measurement using the two conventional slices (longitudinal and transverse) to establish limits [3]. Classically, the normal size of the kidneys is $120 \mathrm{~mm}$ for the height, $60 \mathrm{~mm}$ for the width and $30 \mathrm{~mm}$ for the thickness. Renal hypotrophy is described when the height is less than $90 \mathrm{~mm}$, the width less than $40 \mathrm{~mm}$ and the thickness less than $30 \mathrm{~mm}$. Renal hypertrophy is defined by a height greater than $120 \mathrm{~mm}$. 
This study has been approved by the management of the university hospital center Yalgado Ouédraogo of Ouagadougou, in the absence of an institutional ethics committee. An information leaflet detailing the objectives has been proposed to the identified persons. For those who could not read, the instructions were clearly explained in the dialect of their choice. It was only after this stage that verbal consent was requested and acquired from study participants. We did not observe any cases of refusal to participate. The data was collected under the guise of anonymity and confidentiality. The results of the complementary examinations were immediately communicated and explained to the participants.

Data entry and analysis was done on a micro-computer with Epi-Info software. Quantitative variables were expressed as mean \pm standard deviation and qualitative variables as numbers and percentages. The chi-square test was used to compare the qualitative variables for total numbers $\geq 5$. For total numbers $<5$, we used Fisher's exact test. The Student's t-test was used to compare the means. A p-value $<0.05$ was considered statistically significant.

\section{Results}

The study concerned 100 individuals. The sex ratio was 2.2 and the average age of the patients was $23.9 \pm 6.1$ years. The overall mean serum creatinine was $110.7 \pm 9.5 \mathrm{~mL} / \mathrm{min} / 1.73 \mathrm{~m}^{2}$. The general complete data of patientsis shown in Table 1.

\subsection{Renal Measurements by Ultrasound}

Kidney measurements on ultrasound showed an average height of $94.5 \pm 14.5$ and $96.7 \pm 16.7 \mathrm{~mm}$ for respectively the right and left kidneys. The synthesis of renal measurements on ultrasound is reported in Table 2.

\subsection{Distribution of Renal Heights}

The distribution of renal heights in our sample followed a normal distribution. Thus, the probability that the height of the right kidney be between 79.2 and $109.7 \mathrm{~mm}$ was 0.95 and the probability that the height of the right kidney be less than $79.2 \mathrm{~mm}$ or greater than $109.7 \mathrm{~mm}$ was 0.05 (Figure 1).

The probability that the height of a left kidney be between 81.5 and $111.8 \mathrm{~mm}$ was 0.95 and the probability that the height of a left kidney be less than $81.5 \mathrm{~mm}$ or greater than $111.8 \mathrm{~mm}$ was 0.05 (Figure 2).

\subsection{Factors Associated with Kidney Height Socio-Demographic Factors}

The socio-demographic factor significantly associated with renal height was the sex (Table 3). Thus, the renal height was significantly higher in male.

\subsection{Lifestyle}

In our study, there was no significant association between lifestyle and renal 
Table 1. Socio-demographic, clinical and laboratory data of 10,018 to 30-year-old subjects with normal renal function in Ouagadougou.

\begin{tabular}{|c|c|c|}
\hline Sex ratio: 2.2 & \multicolumn{2}{|c|}{ Body mass index in $\mathrm{kg} / \mathrm{m}^{2}$} \\
\hline Mean age: $23.9 \pm 6.1$ years & \multicolumn{2}{|c|}{$\mathrm{m} \pm$ SD overall: $22.6 \pm 8.7$} \\
\hline Residence & \multicolumn{2}{|c|}{$\mathrm{m} \pm \mathrm{SD}$ men: $22.4 \pm 6.9$} \\
\hline Ouagadougou n (\%): 95 (95) & \multicolumn{2}{|c|}{$\mathrm{m} \pm$ SD women: $23.2 \pm 8.0$} \\
\hline Other residence n (\%): 5 (5) & \multicolumn{2}{|c|}{$\mathrm{SBP}$ in $\mathrm{mmHg}$} \\
\hline Profession & \multicolumn{2}{|c|}{$\mathrm{m} \pm$ overall SD: $117.3 \pm 5.1$} \\
\hline Student n (\%): 65 (65) & \multicolumn{2}{|c|}{$\mathrm{m} \pm \mathrm{SD}$ men: $118.0 \pm 7.2$} \\
\hline Pupil n (\%): 19 (19) & \multicolumn{2}{|c|}{$\mathrm{m} \pm$ SD women: $115.8 \pm 3.5$} \\
\hline Official n (\%): 16 (16) & \multicolumn{2}{|c|}{$\mathrm{DBP}$ in $\mathrm{mm} \mathrm{Hg}$} \\
\hline Lifestyle & \multicolumn{2}{|c|}{$\mathrm{m} \pm \mathrm{SD}$ overall: $74.6 \pm 1.9$} \\
\hline Tobacco $^{\star}$ n (\%): 14 (14) & \multicolumn{2}{|c|}{$\mathrm{m} \pm \mathrm{SD}$ men: $76.2 \pm 2.2$} \\
\hline Alcohol $^{\star *} \mathrm{n}(\%): 36(36)$ & \multicolumn{2}{|c|}{$\mathrm{m} \pm \mathrm{SD}$ women: $71.0 \pm 3.3$} \\
\hline Sedentary n (\%): 32 (32) & \multicolumn{2}{|c|}{ Creatininemia in $\mu \mathrm{mol} / \mathrm{L}$} \\
\hline Weight in $\mathrm{kg}$ & \multicolumn{2}{|c|}{$\mathrm{m} \pm$ overall SD: $82.6 \pm 2.5$} \\
\hline $\mathrm{m} \pm \mathrm{SD}: 68.1 \pm 24.9$ & \multicolumn{2}{|c|}{$\mathrm{m} \pm \mathrm{SD}$ men: $86.3 \pm 12.5$} \\
\hline $\mathrm{m} \pm$ SD men: $69.8 \pm 23.2$ & \multicolumn{2}{|c|}{$\mathrm{m} \pm$ SD women: $74.3 \pm 9.9$} \\
\hline $\mathrm{m} \pm$ SD women: $64.3 \pm 24.7$ & \multicolumn{2}{|c|}{ GFR (MDRD) in $\mathrm{mL} / \mathrm{min} / 1.73 \mathrm{~m}^{2}$} \\
\hline Height in $\mathrm{cm}$ & \multicolumn{2}{|c|}{$\mathrm{m} \pm \mathrm{SD}: 110.7 \pm 9.5$} \\
\hline $\mathrm{m} \pm \mathrm{SD}: 173.1 \pm 21.9$ & \multicolumn{2}{|c|}{$\mathrm{m} \pm \mathrm{SD}$ men: $124.3 \pm 5.9$} \\
\hline $\mathrm{m} \pm$ SD men: $176.1 \pm 18.9$ & \multirow{2}{*}{\multicolumn{2}{|c|}{$\mathrm{m} \pm$ SD women: $109.4 \pm 10.4$}} \\
\hline $\mathrm{m} \pm \mathrm{SD}$ women: $166.4 \pm 14.6$ & & \\
\hline \multicolumn{3}{|c|}{$\begin{array}{l}*: 3.5 \text { packs-year on average. }{ }^{* *} \text { : occasional consumption. DBP: diastolic blood pressure. GFR: glomerular } \\
\text { filtration rate. } \mathrm{m} \pm \mathrm{SD} \text { : mean } \pm \text { standard deviation. } \mathrm{MDRD} \text { : modification of diet in renal disease. SBP: } \\
\text { systolic blood pressure. }\end{array}$} \\
\hline & Right Kidney & Left Kidney \\
\hline \multicolumn{3}{|l|}{ Height } \\
\hline $\mathrm{m} \pm \mathrm{SD}$ in $\mathrm{mm}$ & $94.5 \pm 14.5$ & $96.7 \pm 16.7$ \\
\hline$<90 \mathrm{~mm} \mathrm{n}(\%)$ & $27(27)$ & $18(18)$ \\
\hline$\geq 90 \mathrm{~mm} \mathrm{n}(\%)$ & $73(73)$ & $82(82)$ \\
\hline \multicolumn{3}{|l|}{ Width } \\
\hline $\mathrm{m} \pm \mathrm{SD}$ (extreme) in $\mathrm{mm}$ & $38.7 \pm 10.7$ & $42.7 \pm 16.7$ \\
\hline$<40 \mathrm{~mm} \mathrm{n}(\%)$ & $55(55)$ & $26(26)$ \\
\hline$\geq 40 \mathrm{~mm} \mathrm{n}(\%)$ & $45(45)$ & $74(74)$ \\
\hline \multicolumn{3}{|l|}{ Thickness } \\
\hline $\mathrm{m} \pm \mathrm{SD}$ (extreme) in $\mathrm{mm}$ & $36.3 \pm 10.3$ & $36.8 \pm 10.8$ \\
\hline$<30 \mathrm{~mm} \mathrm{n}(\%)$ & $4(4)$ & $6(6)$ \\
\hline$\geq 30 \mathrm{~mm} \mathrm{n}(\%)$ & $96(96)$ & $94(94)$ \\
\hline
\end{tabular}

$\mathrm{m} \pm \mathrm{SD}:$ mean \pm standard deviation.

height (Table 4).

\subsection{Anthropometric Data}

In our study, the average kidney height for subjects less than $1.70 \mathrm{~m}$ and those 
Table 3. Association between renal height and socio-demographic factors of 18 to 30 -year-old subjects with normal renal function in Ouagadougou.

\begin{tabular}{|c|c|c|c|c|}
\hline & \multicolumn{2}{|c|}{ Right kidney } & \multicolumn{2}{|c|}{ Left kidney } \\
\hline & $\begin{array}{c}\text { Height } \\
\mathrm{m} \pm \mathrm{SD} \text { in } \mathrm{mm}\end{array}$ & $\mathrm{p}$ & $\begin{array}{c}\text { Height } \\
\mathrm{m} \pm \mathrm{SD} \text { in } \mathrm{mm}\end{array}$ & $\mathrm{p}$ \\
\hline Sex & & 0.009 & & 0.008 \\
\hline Man & $94.8 \pm 14.8$ & & $96.8 \pm 13.6$ & \\
\hline Woman & $93.6 \pm 11.6$ & & $96.7 \pm 6.7$ & \\
\hline Age in years & & NS & & NS \\
\hline$<20$ & $86.6 \pm 6.6$ & & $93.0 \pm 10.0$ & \\
\hline$[20-25]$ & $95.6 \pm 14.5$ & & $97.3 \pm 17.3$ & \\
\hline$[25-30]$ & $94.0 \pm 14.0$ & & $96.5 \pm 12.4$ & \\
\hline$\geq 30$ & $88.0 \pm 2.6$ & & $90.0 \pm 3.0$ & \\
\hline Residence & & NS & & NS \\
\hline Ouagadougou & $94.8 \pm 14.7$ & & $96.7 \pm 16.7$ & \\
\hline Outside of ouagadougou & $89.4 \pm 6.7$ & & $96.8 \pm 11.1$ & \\
\hline Profession & & NS & & NS \\
\hline Student & $90.7 \pm 8$ & & $94.8 \pm 4.5$ & \\
\hline Pupil & $91.1 \pm 3.6$ & & $42.3 \pm 0.7$ & \\
\hline Official & $91 \pm 6$ & & $94 \pm 5.6$ & \\
\hline
\end{tabular}

$\mathrm{m} \pm \mathrm{SD}$ : mean \pm standard deviation. NS: not significant.

Table 4. Association between kidney height, antecedents, and lifestyle of 18 to 30-year-old subjects with normal renal function in Ouagadougou.

\begin{tabular}{|c|c|c|c|c|}
\hline & \multicolumn{2}{|c|}{ Right kidney } & \multicolumn{2}{|c|}{ Left kidney } \\
\hline & $\begin{array}{c}\text { Height } \\
\mathrm{m} \pm \mathrm{SD} \text { in } \mathrm{mm}\end{array}$ & $\mathrm{p}$ & $\begin{array}{c}\text { Height } \\
\mathrm{m} \pm \mathrm{SD} \text { in } \mathrm{mm}\end{array}$ & $\mathrm{p}$ \\
\hline Smoker & & NS & & NS \\
\hline Yes & $95.3 \pm 8.2$ & & $98.5 \pm 15.5$ & \\
\hline No & $94.4 \pm 14.3$ & & $96.5 \pm 16.4$ & \\
\hline Chew Tobacco & & NS & & NS \\
\hline Yes & $104 \pm 9$ & & $104.7 \pm 9.6$ & \\
\hline No & $94.3 \pm 14.2$ & & $96.5 \pm 16.5$ & \\
\hline Alcohol & & NS & & NS \\
\hline Yes & $98.7 \pm 4.7$ & & $101.5 \pm 11.5$ & \\
\hline No & $94.3 \pm 14.3$ & & $96.5 \pm 16.4$ & \\
\hline Sedentary & & NS & & NS \\
\hline Yes & $93.4 \pm 13.4$ & & $96.3 \pm 9.2$ & \\
\hline No & $94.7 \pm 14.6$ & & $96.7 \pm 16.7$ & \\
\hline
\end{tabular}

$\mathrm{m} \pm \mathrm{SD}$ : mean \pm standard deviation. NS: not significant. 
Right kidney height

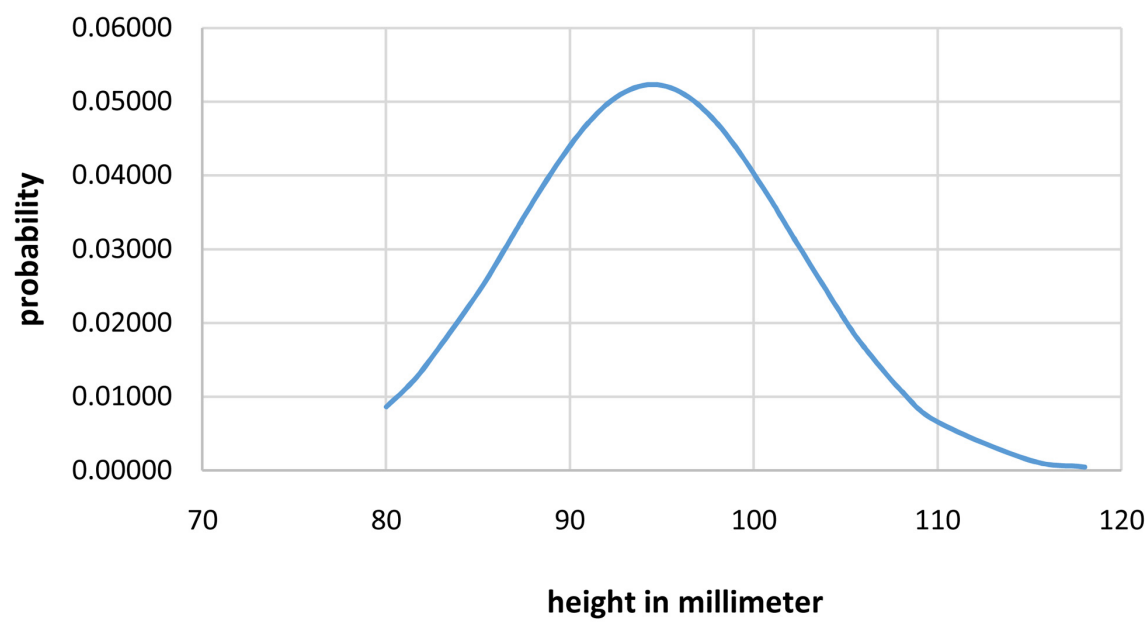

Figure 1. Gauss curve representing the distribution of subjects according to the height of the right kidney. Mean $=94.5$; standard deviation $=14.5 ; \mathrm{n}=100$. Horizontal axis: right kidney heignt in millimeter. Vertical axis: probability.

\section{Left Kidney height}

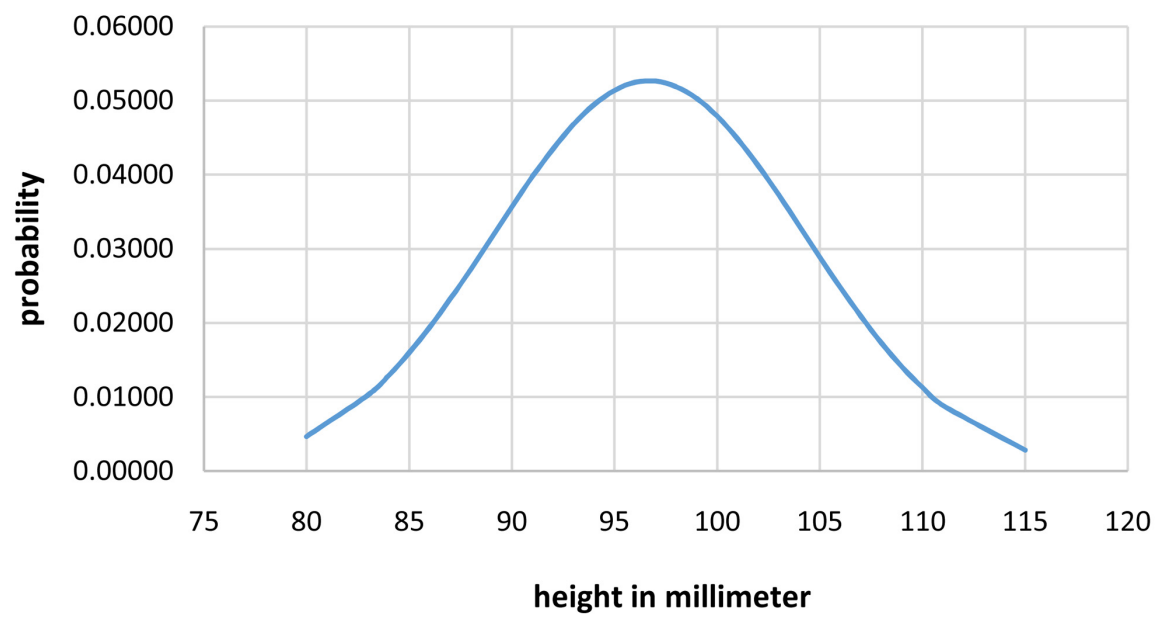

Figure 2. Gauss curve representing the distribution of subjects according to the height of the left kidney. Mean $=96.7$; standard deviation $=16.7 ; \mathrm{n}=100$. Horizontal axis: left kidney heignt in millimeters. Vertical axis: probability.

with a size greater than or equal to $1.70 \mathrm{~m}$ was respectively $91.4 \pm 11.6$ and $95.4 \pm$ $15.5 \mathrm{~mm}$ for the right kidney and 92.9. \pm 13.1 and $97.8 \pm 15 \mathrm{~mm}$ for the left kidney. The kidney was significantly higher in height for subjects greater than or equal to $1.70 \mathrm{~m}$ both on the right $(\mathrm{p}=0.002)$ and on the left $(\mathrm{p}=0.005)$ (Table 5 ). Likewise, the height of the kidney of subjects with a BMI greater than or equal to $25 \mathrm{~kg} / \mathrm{m}^{2}$ was greater than that of subjects with a BMI less than 25 (Table 5).

\subsection{Laboratory Factors}

In subjects with serum creatinine less than $70 \mu \mathrm{mol} / \mathrm{L}$ had an average height of 
Table 5. Association between kidney height and anthropometric data of 18 to 30-year-old subjects with normal renal function in Ouagadougou.

\begin{tabular}{|c|c|c|c|c|}
\hline & \multicolumn{2}{|c|}{ Right kidney } & \multicolumn{2}{|c|}{ Left kidney } \\
\hline & $\begin{array}{c}\text { Height } \\
\mathrm{m} \pm \mathrm{SD} \text { in } \\
\mathrm{mm}\end{array}$ & $\mathrm{p}$ & $\begin{array}{c}\text { Height } \\
\mathrm{m} \pm \mathrm{SD} \text { in } \\
\mathrm{mm}\end{array}$ & $\mathbf{P}$ \\
\hline Height & & 0.02 & & 0.005 \\
\hline$<1.70 \mathrm{~m}$ & $91.4 \pm 11.6$ & & $92.9 \pm 13.1$ & \\
\hline$\geq 1.70 \mathrm{~m}$ & $95.4 \pm 15.5$ & & $97.8 \pm 15$ & \\
\hline Weight & & NS & & NS \\
\hline$<60 \mathrm{~kg}$ & $91.2 \pm 11.2$ & & $93.8 \pm 13.7$ & \\
\hline$[60-80] \mathrm{kg}$ & $94.8 \pm 14.8$ & & $97.1 \pm 14.1$ & \\
\hline$\geq 80 \mathrm{~kg}$ & $97.5 \pm 9.5$ & & $98.8 \pm 11.8$ & \\
\hline Body mass index & & 0.04 & & 0.02 \\
\hline$<25 \mathrm{~kg} / \mathrm{m}^{2}$ & $94.2 \pm 14.3$ & & $96.1 \pm 16.3$ & \\
\hline$\geq 25 \mathrm{~kg} / \mathrm{m}^{2}$ & $95.5 \pm 8.1$ & & $98.1 \pm 10.9$ & \\
\hline
\end{tabular}

$\mathrm{m} \pm \mathrm{SD}$ : mean \pm standard deviation. NS: not significant.

the right and left kidneys of $97 \pm 8$ and $98.7 \pm 11.7 \mathrm{~mm}$, respectively. For subjects with serum creatinine greater than or equal to $70 \mu \mathrm{mol} / \mathrm{L}$, the mean kidney height was $94.3 \pm 14.3$ and $96.6 \pm 13.6 \mathrm{~mm}$, respectively. The differences observed were not significant.

\subsection{Comparison of Renal Size Means}

In average, the right kidney had a height of $94.5 \pm 14.5 \mathrm{~mm}$, a width of $38.7 \pm$ $10.7 \mathrm{~mm}$ and a thickness of $36.3 \pm 10.3 \mathrm{~mm}$. Compared to the right kidney, the average size of which was $96.7 \pm 16.7,42.7 \pm 16.7$ and $36.8 \pm 10.8 \mathrm{~mm}$ respectively for heigth, width and thickness, the left kidney was larger ( $\mathrm{p}=$ 0.0001 for the three types of measurements).

\section{Discussion}

We used ultrasound for the kidneys measurements. This ultrasound technique has the advantage of being safe and financially accessible. It is a first-line imaging. When performed by an experienced operator, the ultrasound provides exciting results. However, CT scan is more accurate and easier to reproduce [4] but it is much more expensive. Our choice to use two ultrasound operators helps improve the accuracy.

We reported mean height of $94.5 \pm 14.5 \mathrm{~mm}$ for the right kidney and $96.7 \pm$ $16.7 \mathrm{~mm}$ for the left kidney, and even kidneys with $80 \mathrm{~mm}$ of height were compatible with normal kidney function. These sizes are smaller than the 120 $\mathrm{mm}$ appearing in classic anatomy books [1] described in Caucasian. Other African authors report means that, although slightly higher than ours, are well below $120 \mathrm{~mm}$. Indeed, Ramilitiana et al. in Madagascar, Agboton et al. in Benin and Okoye et al. in Nigeria noted the mean of the height for the right and left 
kidney between 98 to $106 \mathrm{~mm}$ [3] [5] [6]. In Mexico, Oyuela-Carrasco et al. [7] found a mean of $104.3 \pm 6.5 \mathrm{~mm}$ for the right kidney and $105.8 \pm 7.5 \mathrm{~mm}$ for the left kidney. In our study as well as in others, the right kidney was lower than the left, certainly because of the presence of the liver above the right kidney.

We did not find any significant association between kidney height and age, certainly due to the age homogeneity of our sample. We should know that the height varies depending on age. This has been well demonstrated in the study of Buchholz et al. [2] based on a population aged between 13 and 80 years. Thus, in their sample, the size of the kidney increased until the 3rd decade, remained stable throughout the middle age and then decreased. Like most studies [2] [3] [6] [8], we confirmed that male had a higher kidney size than female. The influence of the male sex hormones lead in general to a higher weight and height in man compared to woman. It is known the height of the kidney is proportional to these two anthropometric parameters [7] [9] [10]. Our study has moreover confirmed this association between these parameters and the renal height.

\section{Limits of the Study}

The results of our study could not be generalized to the national level because of our convenience sampling. Also, normal kidney function was determined by the estimation of GFR by the MDRD formula. Although this method is wellappropriated for the weights and ages in our study, the accurate measurement of the GFR with a standard method (however costly) would have given us the preliminary study, with exciting results th certainty. Despite these limitations, we have reached to the end of this at can serve as a basis for practitioners in our country.

\section{Conclusion}

Although our study cannot be generalized to the population of our country, suggests that the kidneys of the healthy Burkinabe are smaller than what is reported in anatomy books. Our study, which is preliminary, should be deepened through a national study. If this study confirms the present results, some questions may be asked. Indeed, if the GFR is proportional to a healthy kidney size, we can wonder if the Black Burkinabe (African by extension) does not have a lower GFR at birth. Could this contribute to a faster progression of chronic renal failure in such a population? Moreover, we should consider, in the nephrology assessment of Burkinabe patient, the results of the renal biometry that we report.

\section{Conflicts of Interest}

The authors do not declare any conflict of interest.

\section{References}

[1] Rouvière, H. and Delmas, A. (2002) Anatomie Humaine: Descriptive, topographique et fonctionnelle. $15^{\text {ème }}$ édition, Masson, Paris. 
[2] Buchholz, N.P., Abbas, F., Biyabani, S.R., Afzal, M., Javed, Q., Rivzi, I., et al. (2000) Ultrasonographic Renal Size in Individuals without Known Renal Disease. Journal Of Pakistan Medical Association, 50, 12-16.

[3] Agboton, B.L., Yepke, P., Vigan, J., Gandji, S., Klaissa, E., Aguemon, B., et al. (2015) Biométrie rénale des adultes béninois apparemment sains comparée à celle des hémodialysés. West African Journal of Research for Health, 4, 25-28.

[4] Nahum, H., Frijo, G., Grenier, P., Lewin Zeitoun, M. and Vignaux, O. (2014) Traité d'imagerie médicale. 2è édition, Lavoisier, Paris.

[5] Oyuela-Carrasco, J., Rodriguez-Castellanos, F., Kimura, E., Delgado-Hernandez, R.E. and Herrera-Felix, J.P. (2009) Renal Length Measured by Ultrasound in Adult. Mexican Population Nefrologia, 29, 30-34.

[6] Okoye, I.J., Agwu, K.K. and Idigo, F.U. (2005) Normal Sonographic Renal Length in Adult Southeast Nigerian. African Journal of Medical and Health Sciences, 34, 129-131.

[7] Ramilitiana, B., Dodo, M., Rakotoarimanga, H.N., Randriamboavonjy, R.L. and Randriamarotia, W.F. (2016) Dimensions rénales en service de Néphrologie clinique. The Pan African Medical Journal, 24, Article No. 117. https://doi.org/10.11604/pamj.2016.24.117.9411

[8] Glodny, B., Unterholzer, V., Taferner, B., Hofmann, K.J., Rehder, P., Strasak, A., et al. (2009) Normal Kidney Size and Its Influencing Factors-A 64 Slice MDCT Study of 1040 Asymptomatic Patients. BMC Urology, 9, Article No. 19. https://doi.org/10.1186/1471-2490-9-19

[9] Moulion Tapouh, J.R., Moifo, B., Kaze, F.F.J., Kandjan Dayo, A.E., Tagni, Z.D. and Gonsu, F.J. (2016) Biométrie rénale normale au scanner dans un groupe d'adultes camerounais à Yaoundé. JAIM, 8, 141-147.

[10] Saeed, Z., Miza, W., Sayani, R., Sheikh, A., Yazdani, I. and Hussain, S.A. (2012) Sonographic Measurement of Renal Dimensions in Adults and Its Correlates. International Journal of Collaborative Research on Internal Medicine and Public Health, 4, 1626-1641. 


\section{Appendix}

\section{FICHE DE COLLECTE} I/IDENTITE

- Numéro d'identification:

- Age: .........

- Sexe: M /_/, F /_/

- Lieu de résidence:

- Profession:

- Ville:

- Contact:

\section{II/ ANTECEDENTS}

Personnels:

- Terme à la naissance:

- Gémellité: Oui /_/ Non /_/

- Complications à l'accouchement: Oui /_/ Non /_/ (si oui préciser.........)

- Hématurie: Oui /_/ Non /_/

- Pyurie: Oui /_/ Non /_/

- Edème de type rénal: Oui /_/ Non /_/

- Brûlures mictionnelles: Oui /_/ Non/_/

- Infections ORL: Oui /_/ Non /_/

- HTA: Oui /_/ Non /_/ (si oui date de début..........)

- Maladie rénale: Oui /_/ Non /_/ (si oui date de début..........)

- Diabète: Oui /_/ Non /_/ (si oui date de début......)

- Hémoglobinopathie: Oui /_/ Non /_/ (si oui date de début..........)

- Cardiopathie: Oui /_/ Non /_/ (si oui date de début..........)

Familiaux:

- HTA: Oui /_/ Non /_/

- Diabète: Oui /_/ Non /_/ (si oui quel type..............)

- Cardiopathie: Oui /_/ Non/_/

- Maladie rénale: Oui /_/ Non /_/

- Autres:

$>$ Mode de vie:

- Tabac fumé: Oui /_/ Non /_/ (si oui combien de paquets années..........)

- Tabac chiqué: Oui /_/ Non /_/

- Alcool: Oui /_/ Non /_/ (si oui quelle quantité...........)

- Sédentarité: Oui /_/ Non /_/

Autres Antécédents:

III/DONNEES CLINIQUES

- Etat général selon OMS: /_/

- Capable d'une activité identique à celle précédent la maladie, sans aucune restriction: 0 .

- Activité physique diminuée mais ambulatoire et capable de mener un travail: 1. 
- Ambulatoire et capable de prendre soin de soi, incapable de travailler. Alité moins de $50 \%$ de son temps: 2 .

- Capables de seulement quelques soins personnels. Alité ou en chaise plus de 50\% du temps: 3 .

- Incapable de prendre soin de lui-même, alité ou en chaise en permanence: 4.

- Taille:

- Poids:

- Indice de masse corporelle:

- Bruits du cœur:

- Pression artérielle:

- Les mensurations du foie:

IV/DONNEES BIOLOGIQUES

- la créatininémie:

- le débit de filtration glomérulaire selon MDRD:

V/BIOMETRIE RENALE

REIN DROIT:

- Hauteur:

$1=($ augmentée $)>120$

$2=($ normale $) 85-120$

$3=($ diminuée $)<85$

- Largeur:

$1=$ (augmentée) $>60$

$2=$ (normale) $35-60$

$3=($ diminuée $)<35$

- Epaisseur:

$1=$ (augmentée $)>52$

$2=$ (normale) $28-52$

$3=($ diminuée $)<28$

- Bonne différenciation cortico-médullaire: Oui /_/, Non /_/ REIN GAUCHE:

- Hauteur:

$1=($ augmentée $)>120$

$2=($ normale $) 85-120$

$3=$ (diminuée $)<85$

- Largeur:

$1=$ (augmentée $)>60$

$2=$ (normale) $35-60$

$3=($ diminuée $)<35$

- Epaisseur:

$1=($ augmentée $)>52$

$2=($ normale $) 28-52$

$3=$ (diminuée $)<28$

- Diamètre: 
$1=($ augmentée $)>77$

$2=$ (normale) $49-77$

$3=($ diminuée $)<49$

- Bonne différenciation cortico-médullaire: Oui /_/, Non /_/

Symétrie de la taille des reins: Oui /_/ Non /_/

\section{COLLECTION SHEET}

I/IDENTITY

- ID number:

- Age:

- Sex: M/_/, F/_/

- Place of residence:

- Profession:

- City:

- Contact:

\section{II/BACKGROUND}

Personal:

- Term at birth:

- Twinning: Yes /_/ No /_ /

- Complications during childbirth: Yes /_ / No / _ / (if yes specify .........)

- Hematuria: Yes /_/ No /_ I

- Pyuria: Yes /_/ No /_/

- Edema of renal type: Yes / _ / No / _ /

- Micturition burns: Yes / _ / No / _ /

- ENT infections: Yes /_/ No/_ /

- HBP: Yes /_ / No / _ / (if yes start date ...........)

- Renal disease: Yes / _ / No / _ / (if yes start date ..........)

- Diabetes: Yes / _ / No / _ / (if yes start date ......)

- Hemoglobinopathy: Yes / _ / No / _ / (if yes start date ...........)

- Cardiopathy: Yes / _ / No / _ / (if yes start date ..........)

Family:

- HBP: Yes /_/ No /_/

- Diabetes: Yes /_ / No / _ / (if yes which type ..............)

- Cardiopathy: Yes /_/ No/_/

- Renal disease: Yes/_/ No / _ /

- Other:

Lifestyle:

- Smoked tobacco: Yes /_ / No / _ / (if yes how many packages years ..........)

- Chewed tobacco: Yes /_ / No/_ I

- Alcohol: Yes / _ / No / _ / (if yes what quantity ...........)

- Sedentary lifestyle: Yes / _ / No / _ /

Other History:

III/CLINICAL DATA

- General condition according to WHO: / _ / 
- Capable of an activity identical to that preceding the disease, without any restriction: 0 .

- Reduced but ambulatory physical activity capable of carrying out work: 1

- Ambulatory and able to take care of oneself, unable to work. Bedridden less than $50 \%$ of his/her time: 2 .

- Capable of only some personal care. In bed or in a chair more than $50 \%$ of the time: 3 .

- Unable to take care of himself, bedridden or in a chair permanently: 4 .

- Cut:

- Weight:

- Body mass index:

- Noise of the heart:

- Arterial pressure:

- The liver measurements:

IV/BIOLOGICAL DATA

- creatinine level:

- the glomerular filtration rate according to MDRD:

V/RENAL BIOMETRY

RIGHT KIDNEY:

- Height:

$1=($ increased $)>120$

$2=$ (normal) $85-120$

$3=($ decreased $)<85$

- Width:

$1=($ increased $)>60$

$2=($ normal $) 35-60$

$3=($ decreased $)<35$

- Thickness:

$1=($ increased $)>52$

$2=$ (normal) $28-52$

$3=($ decreased $)<28$

- Good cortico-medullary differentiation: Yes / _ /, No / _ /

LEFT KIDNEY:

- Height:

$1=($ increased $)>120$

$2=($ normal $) 85-120$

$3=($ decreased $)<85$

- Width:

$1=($ increased $)>60$

$2=$ (normal) $35-60$

$3=($ decreased $)<35$

- Thickness: ..........

$1=($ increased $)>52$ 
$2=($ normal $) 28-52$

$3=($ decreased $)<28$

- Diameter: ...........

$1=$ (increased $)>77$

$2=($ normal $) 49-77$

$3=($ decreased $)<49$

- Good cortico-medullary differentiation: Yes /_/, No / _ /

Symmetry of kidney size: Yes / _ / No / _ / 